\title{
Pseudomonas aeruginosa
}

National Cancer Institute

\section{Source}

National Cancer Institute. Pseudomonas aeruginosa. NCI Thesaurus. Code C86696.

A species of facultatively anaerobic, Gram neg ative, rod shaped bacteria in the phylum Proteobacteria. This species is motile, non spore forming, produces pyorubin, pyocyanin and fluorescein and has minimal nutrient requirements. P. aerug inosa is an opportunistic pathogen found in soil, water and as a part of skin flora that can cause lethal infections in cystic fibrosis patients, burn victims and immunocompromised individuals. 